\title{
Growth inhibition of Staphylococcus aureus by chicken egg yolk antibodies
}

\author{
Marco Cesar Cunegundes Guimarães ${ }^{1}$, Lívia Gomes Amaral ${ }^{1}$, \\ Letícia Batista Azevedo Rangel ${ }^{1}$, lan Victor Silva ${ }^{1}$, Claudia Gomes \\ Fernandes Matta ${ }^{1}$ and Marcos Fernando de Rezende Matta ${ }^{2}$ \\ ${ }^{1}$ Laboratory of Cellular and Molecular Biology of Human Cancer, UFES, Vitória, ES, Brazil \\ 2 Immunogenetics, Universidade Estadual do Norte Fluminense Darcy Ribeiro, Campos dos Goytacazes, RJ, Brazil
}

Received: 2008.12.23, Accepted: 2009.05.20, Published online: 2009.08.20

(C) L. Hirszfeld Institute of Immunology and Experimental Therapy, Wrocław, Poland 2009

\begin{abstract}
Introduction: The aim was to evaluate the ability of egg yolk antibody (IgY) in blocking Staphylococcus aureus growth in vitro. Materials and Methods: Specific IgY was produced by immunizing hens with formalin-killed S. aureus (ATCC 33593). Specific IgY against $S$. aureus was obtained from the yolks of their eggs with a carrageenan solution. IgY was identified by SDS-PAGE and Western blot and its activity against $S$. aureus was tested by ELISA. A growth inhibition assay and protein concentration determination were also conducted.

Results: ELISA indicated that the IgY was specific to the antigen; this activity was confirmed by Western blotting. The growth of $S$. aureus was inhibited by the specific IgY at concentrations of $1-5 \mu \mathrm{g} / \mathrm{ml}$ The bacteriostatic function of IgY appeared to result possibly from the interaction of $\mathrm{IgY}$ with surface components of $S$. aureus. In vitro experiments showed that the immunoglobulin from egg yolk interfered with the culture growth of the $S$. aureus.

Conclusion: These findings indicate that eggs from hens immunized with appropriate antigens are a potentially useful source of passive immunity.
\end{abstract}

Key words: inhibition of bacterial growth, chicken egg yolk antibody, ELISA and Staphylococcus aureus.

Corresponding author: Marcos F. R. Matta, LMGA, CCTA, UENF, Alberto Lamego Av., 2000, Campos dos Goytacazes, RJ, Brazil, Zip code: 28013-600, tel.: +55 22-27282856, e-mail: matta@uenf.br

\section{INTRODUCTION}

Staphylococcus aureus is a bacterium commonly found on the skin and nose of healthy animals and humans (Jablonski and Bohach 2001; Moreillon et al. 2005). The major reservoirs of the organism are infected udders, teat canals, and teat lesions, but these bacteria have also been found on teat skin, muzzles, nostrils, and vagina (Roberson et al. 1994). The bacteria are spread to uninfected quarters by teat cup liners, milkers' hands, washcloths, and flies (Chambers 2001; Marshall et al. 2000; Pereira et al. 2002; Roberson et al. 1994; Roghmann et al. 2005). S. aureus produces toxins that destroy cell membranes and can directly damage milk-producing tissue (Balaban and Rasooly 2000; Bohach and Foster 2000). This infection occasionally causes inflammation in humans and animals (Bohach and Foster 2000; Jablonski and Bohach 2001). Mastitis is one of the most costly problems in the dairy industry (Crossley and Archer 1997; Nickerson et al. 1995). The problem is related principally to antibiotic use (Fox et al. 2000). Staphylococci are inherently susceptible to most antibiotics (Lindberg et al. 2004; Livemore 2000), but antibiotic residues are undesirable in milk products for a number of reasons (Allison 1985; Booth and Harding 1986; McEven et al. 1992). Such residues may be detrimental to the manufacture of certain cultured milk products, and antibiotic use in animal production contributes to microbe resistance (Belschner et al. 1996; Kirk et al. 2002; Oliver et al. 1992). A wide range of alternatives to antibiotics have emerged as a result of their ban (organic acids, probiotics, herb extracts, and others), of which passive immunization with antibodies is an approach with great potential due to its high specificity (Sol et al. 1997). 
Passive immunization is basic to human and animal health. One way is the use of antibodies (Doyle 2001). The ability of antibodies to bind antigen with a high degree of affinity and specificity has led to their ubiquitous use in a variety of resources (Berghman et al. 2005; Casadevall 1996). Their use in diagnostic assays and as therapeutics has had a profound impact on improving the health and welfare of both humans and animals (Casadevall and Scharff 1994). However, the method has associated problems in terms of cost and productivity.

Recently, the utilization of $\operatorname{IgY}$ antibodies from the eggs of chickens which were immunized with pathogens has been the focus of attention in immunotherapy and diagnosis since the birds can actively transfer immunoglobulin to the egg yolk at the same concentration levels as in mammals (Buchwald and Profski 2003; Sunwoo et al. 2002). The use of chicken antibody on a large scale offers several advantages, such as low costs, large yield and scaleable production and storability. The efficacy of IgY has been demonstrated in several applications, for example the treatment and prevention of fatal enteric colibacillosis in neonatal piglets and calves, viral diarrhea in infants, dental caries, canine parvovirus, and snake venom (Mine and Kovacs-Nolan 2002; Schade et al. 2005; Schade et al. 1997; Shin et al. 2002). Despite all the advantages offered, the $\operatorname{IgY}$ obtained from the egg yolk of immunized hens need to be better evaluated.

This article therefore provides a simple and efficient way of producing IgY antibodies against $S$. aureus. Chicken anti-S. aureus IgY was generated in six immunized White Leghorn hens using aluminum hydroxide (alum) as adjuvant. In vitro experiments showed that the immunoglobulin from the egg yolk interfered with bacterial growth. These findings indicate that the eggs of hens immunized with appropriate antigens have potential use as a source of passive immunity.

\section{MATERIALS AND METHODS}

\section{Bacterial strains, culture conditions, and antigen preparation}

A strain of $S$. aureus ATCC 33593 (American Type Culture Collection, Manassas, VA, USA) was obtained as freeze-dried pellet cultures. S. aureus was processed as described by Fioretto et al. with some modifications (Fioretto et al. 2005). Briefly, the culture was rehydrated by the addition of $0.3 \mathrm{ml}$ of tryptic soy broth (TSB, Merck, Germany) and a stock culture was then prepared on tryptic soy agar (Difco, USA), incubated at $37^{\circ} \mathrm{C}$ for $24 \mathrm{~h}$, and stored at $4^{\circ} \mathrm{C}$. To revive the microorganisms, a single pellet of the culture was resuspended in $5 \mathrm{ml}$ of tryptic soy broth (TSB) followed by incubation at $37^{\circ} \mathrm{C}$ for $48 \mathrm{~h}$. Further dilutions in TSB were necessary to achieve a concentration of approximately $10^{8}-10^{9}$ colony forming units (CFU/ml S. aureus ATCC 33593).
After incubation, the cells were collected and suspended in phosphate-buffered saline (PBS, pH 7.2) and centrifuged at $5000 \times \mathrm{g}$ for $15 \mathrm{~min}$. Then the cells were treated with $3.7 \%$ formalin $\left(\mathrm{CH}_{2} \mathrm{O}\right)$ overnight. Inactivated cells were washed three times with PBS, suspended using sterile PBS, and their concentration adjusted to $2.6 \times 10^{4}$ cells $/ \mathrm{ml}$. The cells were aliquoted for storage at $-70^{\circ} \mathrm{C}$. The antigen suspension was prepared with $500 \mu \mathrm{l}$ of the $S$. aureus solution $\left(2.6 \times 10^{4}\right.$ cells $\left./ \mathrm{ml}\right)$ added to 500 $\mu \mathrm{l}$ of alhydrogel $\left(\mathrm{Al}(\mathrm{OH})_{3}\right.$; Accurate Chemical \& Scientific Co., Westbury, NY, USA) as adjuvant.

\section{Immunization of hens}

Six laying White Leghorn hens 15 weeks old, obtained from Universidade Estadual do Norte Fluminense Darcy Ribeiro breeders, were immunized by injecting the antigen solution into the pectoral muscle. Three injections of $1 \mathrm{ml}$ of the antigen solution (bacteria mixed with alhydrogel) were given. The first immunization was made by intramuscular injection with $1 \mathrm{ml}$ of antigen suspension as described above. The second was conducted a week after the first inoculation with the same route and volume as the first. Booster inoculations were given at two-week intervals without adjuvant. The eggs and sera were collected daily and stored at $4^{\circ} \mathrm{C}$ for up to three months until antibody extraction.

\section{Isolation of antibodies from egg yolk}

Eggs were collected from immunized and nonimmunized (control group) hens in one-week intervals after the first immunization and pooled separately. Egg yolk antibodies were extracted from the eggs as described in previous studies (Akita and Nakai 1992; Hatta et al. 1990) with some modifications. Briefly, IgY was isolated from the eggs using $\lambda$ carrageenan solution (Sigma Chemical, Type IV, St. Louis, MO, USA). The egg yolk was physically separated from the egg white and poured into a graduated cylinder by puncturing the yolk membrane. Ten $\mathrm{ml}$ of egg yolk was diluted to 100 $\mathrm{ml}$ with $0.1 \% \lambda$ carrageenan (Sigma Chemical). The resulting solution was kept at room temperature for 30 min. The supernatant, i.e. crude IgY solution, was separated by centrifugation $\left(10,000 \times \mathrm{g}\right.$ for $20 \mathrm{~min}$ at $\left.4^{\circ} \mathrm{C}\right)$. The extracted IgY was filtered through $0.2-\mu \mathrm{m}$ membrane filter and stored at $-20^{\circ} \mathrm{C}$ before use.

\section{Electrophoresis and Western blot analysis}

Sodium dodecyl sulfate-polyacrylamide gel electrophoresis (SDS-PAGE) was performed to identify the IgY. Preparations of IgY after the extraction were suspended at protein concentrations of 19.5, 13, 6.5, and $1.3 \mu \mathrm{g} / \mathrm{ml}$ in SDS-PAGE lysis buffer (50 mM Tris- $\mathrm{HCl}$, $\mathrm{pH} 6.8,2 \%$ SDS, $2 \%$ beta-mercaptoethanol, and $0.1 \%$ bromophenol blue). The samples were heated at $95^{\circ} \mathrm{C}$ for $10 \mathrm{~min}$ under reducing conditions. The $\mathrm{IgY}$ solution was separated by $10 \%$ SDS-PAGE and the gel 
was electrophoretically transferred to nitrocellulose membrane filters $(0.45 \mu \mathrm{m}$ pore size; Sigma-Aldrich, USA). Western blot was blocked with blocking buffer $(5 \% \mathrm{w} / \mathrm{v}$ instant nonfat milk powder in PBS). The membranes were washed three times with TBS (pH 7.4) for $5 \mathrm{~min}$ and subsequently incubated with horseradish peroxidase (HRP)-conjugated rabbit anti-chicken antibody (Abcam) for $2 \mathrm{~h}$. After thorough washing, the membrane was placed in peroxidase chromogenic substrate solution (0.01 M PBS, pH 7.4, with $0.05 \%$ 3,3'-diaminobenzidine, $0.03 \%$ nickel chloride, and $0.03 \%$ $\mathrm{H}_{2} \mathrm{O}_{2}$ ) for $15 \mathrm{~s}$ and then immersed in excess distilled water to stop the color development. Finally, the Western blot membrane was digitally recorded using a gel documentation system (UVItec, Cambridge, UK).

\section{Specific activity of IgY against S. aureus}

The specific activity of anti-S. aureus IgY was tested by indirect enzyme-linked immunosorbent assay (ELISA). The $S$. aureus suspension $\left(2.6 \times 10^{4} \mathrm{cell} / \mathrm{ml}\right)$ was diluted to 1:500 in PBS/Tween (PBST). The plate was coated with $100 \mu \mathrm{l}$ of antigen in the appropriate dilution to each well and then incubated overnight at $4^{\circ} \mathrm{C}$. After incubation, the plates were washed three times with $0.05 \%$ PBST. To block unspecific binding, the plate was incubated with $0.5 \%$ gelatin in PBS $(200 \mu \mathrm{l} /$ well $)$ and then washed as described above. The first antibody $(\operatorname{IgY})$, diluted 1:1000 in PBST, was added $(50 \mu \mathrm{l}$ per well), incubated for $1 \mathrm{~h}$ at $41^{\circ} \mathrm{C}$, and washed. The second antibody (anti-chicken enzyme conjugated), diluted 1:3000 in PBST, was added (50 $\mu \mathrm{l}$ per well), incubated for $1 \mathrm{~h}$ at $41^{\circ} \mathrm{C}$, washed three times with PBST, and incubated with $50 \mu \mathrm{l}$ of 2,2'-azino-ethyl-benzthizoline-6-sulfonate (ABTS) substrate solution (KPL, MD, USA). After $30 \mathrm{~min}$ of incubation at room temperature, the reaction was stopped by adding $0.1 \%$ SDS solution. The optical density at $490 \mathrm{~nm}$ was determined for each well with a 96-well plate reader (Molecular Devices Corporation, Sunnyvale, $\mathrm{CA}, \mathrm{USA})$. While $\mathrm{OD}_{\text {sample }} / \mathrm{OD}_{\text {negative }}$ $\geq 2.1$, the maximum dilution multiple of the sample was determined as the $\operatorname{IgY}$ titer.

Enzyme-linked immunosorbent assays were designed to minimize some inter-well, inter-plate, and inter-animal variations and the time variability inherent in all ELISAs. All samples were tested in duplicate wells to help assess inter-well variability. Positive and negative control wells were run in each plate. Wells coated with $S$. aureus were incubated with a 1:100 dilution in PBST of a mouse anti-MRSA antibody ( $S$. aureus) (Prospec TechnoGen ANT-198) and were designated as positive controls. Three types of negative control were run in each plate. The first were serum samples with IgY anti-canine parvovirus. The second, without antigen wells, consisted of two wells for each serum sample (diluted 1:50) that were not coated with the $S$. aureus stock solution. The third, without serum wells, contained all the appropriate reagents except serum.
Growth inhibition assay

This assay was conducted to investigate whether the anti-S. aureus IgY could inhibit $S$. aureus growth in liquid medium as described by the method of Zhen with some modifications (Zhen et al. 2008). The extracted IgY (titer 6400) was dissolved in TSB at concentrations of $1,2.5$, and $5 \mu \mathrm{g} / \mathrm{ml}$. TSB with $5 \mu \mathrm{g} / \mathrm{ml}$ of nonspecific $\operatorname{IgY}$ (IgY anti-canine parvovirus) and without $\operatorname{IgY}$ was the negative or blank control and that with $100 \mu \mathrm{g} / \mathrm{ml}$ of penicillin was the positive control. All preparations were sterilized with a $0.2-\mu \mathrm{m}$ filter and incubated with $2.7 \times 10^{7} \mathrm{CFU} / \mathrm{ml}$ of $S$. aureus (ATCC 33593 ) at $37^{\circ} \mathrm{C}$ with shaking. The suspensions were transferred to a microtiter plate (100 $\mu \mathrm{l}$ per well) at 2-h intervals until the $\mathrm{OD}_{600 \mathrm{~nm}}$ of the blank control reached the stationary phase. The OD value was monitored using a microtiter reader. The growth inhibition assay was conducted for $12 \mathrm{~h}$.

\section{Protein determination}

Protein concentrations in the filtered $\operatorname{IgY}$ extract were determined by the Bradford method using bovine serum albumin as the reference protein.

\section{Statistical analysis}

The results were analyzed by analysis of variance (ANOVA). Student's $t$-test was used to test the significance of differences between the experimental and control groups. Data are presented as means \pm standard deviation. A probability level of $\mathrm{p}<0.05$ was considered statistically significant. ELISA assay validation was performed for some parameters, such as comparison of the samples with the negative and positive controls (Petrie and Watson 1999).

\section{RESULTS}

\section{IgY extraction}

The applied method was effective in isolating IgY from egg yolks as documented by SDS-PAGE and Western blotting (Fig. 1A and B). The $\gamma$ carrageenan solution is not a method sufficient to purify the $\operatorname{IgY}$ extract, but the $\operatorname{IgY}$ obtained was perfectly capable of inhibiting bacterial growth. The major advantage of this method is the simplicity of steps. The results showed there are two main subunits in lanes 1 and 2 (Fig. 1B) that represent the heavy and light chains of IgY.

\section{Specific activity of anti-S. aureus IgY}

The six laying White Leghorn Hens which of the immunization protocol were observed for up to three months. The specific activities of IgY from the chickens immunized with $S$. aureus (ATCC 33593) were moni- 


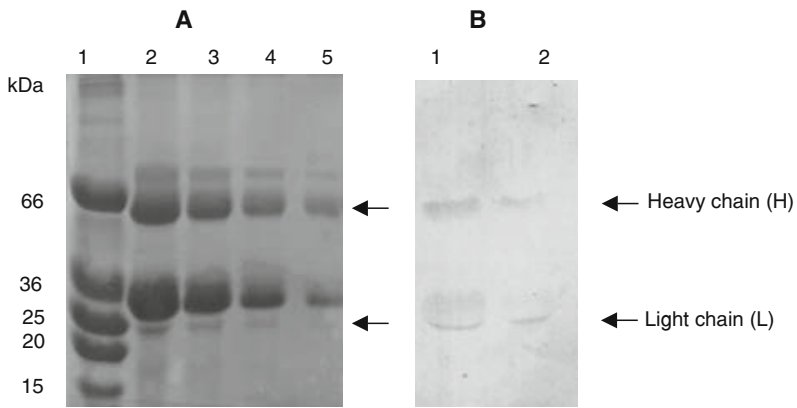

Fig. 1. (A) SDS-PAGE analysis of the IgY extracts. Lane 1: molecular weight marker; lane 2: $19.5 \mu \mathrm{g} / \mathrm{ml}$; lane 3: $13 \mu \mathrm{g} / \mathrm{ml}$; lane 4: $6.5 \mu \mathrm{g} / \mathrm{ml}$; lane $5: 1.3 \mu \mathrm{g} / \mathrm{ml} \mathrm{IgY} \mathrm{extract.} \mathrm{The} \mathrm{samples} \mathrm{were} \mathrm{heated}$ at $95^{\circ} \mathrm{C}$ for $10 \mathrm{~min}$ under reducing conditions. (B) Western blot analysis of IgY extracts. Lane 1: $24.7 \mu \mathrm{g} / \mathrm{ml}$; lane 2: $19.5 \mu \mathrm{g} / \mathrm{ml}$.

tored initially by indirect ELISA. The chickens showed a relatively strong immune response against $S$. aureus. All the animals were seropositive during analysis. Egg yolk anti-S. aureus antibodies were produced after the first inoculation of chickens (Fig. 2). IgY titers reached the highest levels 6 weeks after the first injection (Fig. 2). The results showed that an OD value of 1.96 was attained after an exponential rise. The antibody levels of the immunized animals were significantly higher than those of the controls $(\mathrm{p}<0.05)$. This indicates that the production of specific IgY can be efficiently elicited in chickens using simple protocols of immunization and extraction.

\section{Growth inhibition of S. aureus}

The activity of anti-S. aureus $\operatorname{IgY}$ was shown by the absence of growth when the specific antibodies were added to the $S$. aureus culture (Fig. 3 ). The growth inhi-

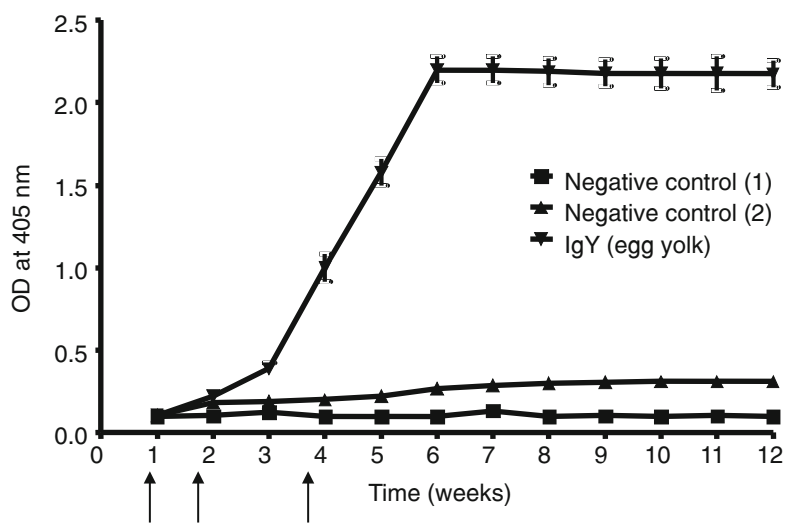

Fig. 2. The kinetics of chicken egg yolk antibody ( $\operatorname{IgY}$ ) production against $S$. aureus ATCC 33593. The IgY antibodies were isolated from egg yolk. The level of IgY activity in a 1000-fold dilution was measured by indirect ELISA using $S$. aureus as an antigen and expressed as the ELISA value (OD at $405 \mathrm{~nm}$ ). Negative control (1) was a nonspecific IgY (IgY anti-canine parvovirus) and negative control (2) was from animals not immunized with $S$. aureus. Values are the mean of six samples (animals). Vertical bars indicate the standard deviation. The arrows indicate the times of immunization.

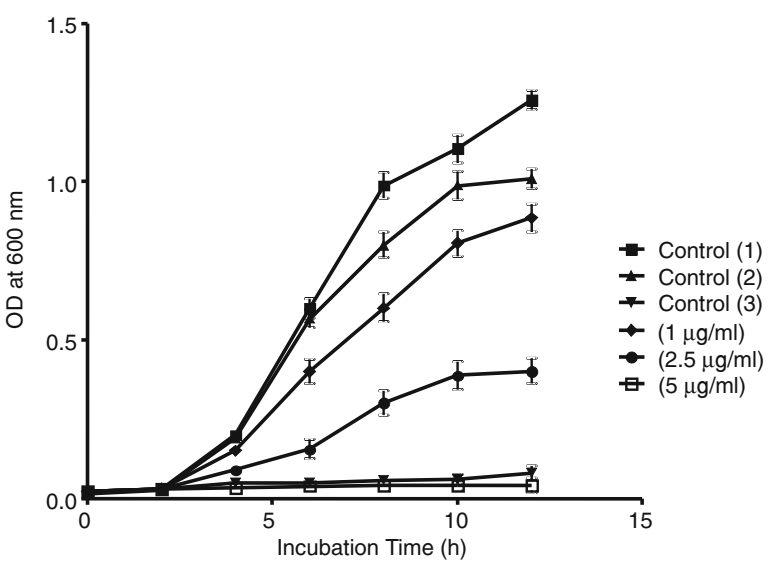

Fig. 3. Growth inhibitory activity of IgY to $S$. aureus using different concentrations $(1,2.5$, and $5 \mu \mathrm{g} / \mathrm{ml})$. Control (1) was without IgY and control (2) with $5 \mu \mathrm{g} / \mathrm{ml}$ of nonspecific $\operatorname{IgY}$ (IgY anti-canine parvovirus); both were used as the negative or blank controls. Control (3) was with $100 \mu \mathrm{g} / \mathrm{ml}$ of penicillin as the positive control.

bition rate varied according to the protein concentration in the filtered $\operatorname{IgY}$ extract $(1,2.5$, and $5 \mu \mathrm{g} / \mathrm{ml})$. pecific IgY with $5 \mu \mathrm{g} / \mathrm{ml}$ protein had the highest inhibitory capacity. There were statistical differences in the three IgY concentrations (Fig. 4). The specific IgY with 1 $\mu \mathrm{g} / \mathrm{ml}$ protein inhibited less than the 2.5 and $5 \mu \mathrm{g} / \mathrm{ml}$ samples. All the tested samples inhibited more than control no. 1 and 2. The validation of IgY anti-S. aureus antibody was made by comparison with the negative control and the blank, in which $S$. aureus growth was explained by the absence of the specific antibodies. The specific IgY of the $5 \mu \mathrm{g} / \mathrm{ml}$ sample was chosen for comparison with control no. 3 , which was the positive control, because it was the concentration that inhibited bacterial growth most, and they were significantly different (Fig. 5).

\section{DISCUSSION}

The present study demonstrates that IgY prepared from the egg yolk of hens immunized with $S$. aureus is effective in the growth inhibition of $S$. aureus in culture.

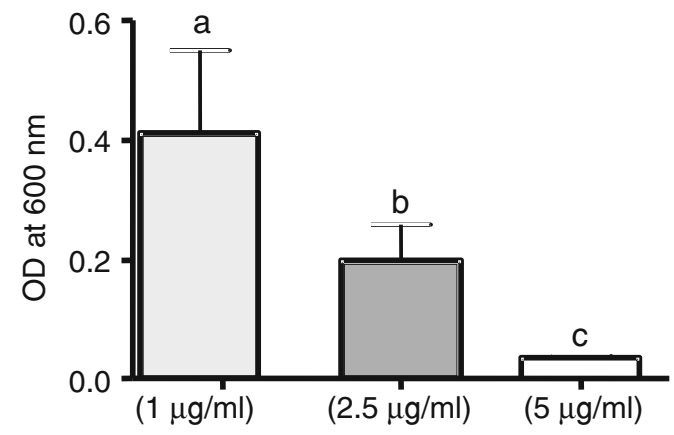

Fig. 4. Comparison of the growth inhibitory effect of the three concentrations of IgY. Bars with different superscripts are significantly different $(\mathrm{p}<0.005)$. 


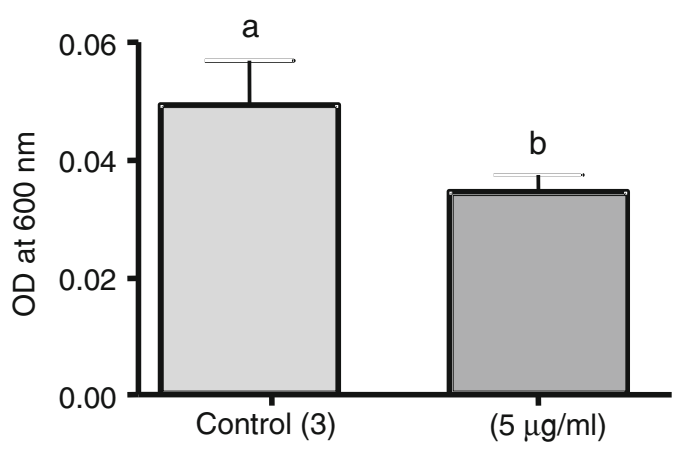

Fig. 5. Comparison of the growth inhibitory effects of control no. 3 (a) and the specific $\operatorname{IgY}$ with $5 \mu \mathrm{g} / \mathrm{ml}$ (b). Bars with different superscripts are significantly different $(\mathrm{p}<0.005)$.

S. aureus causes animal and human infections which can frequently be cured using antimicrobial therapy, but the large-scale use of antibiotics leads to the emergence of antibiotic-resistant strains. An alternative to antibiotic use is serum therapy. Serum therapy is the administration of immune sera from immunized animals for the prevention or treatment of infectious diseases. Antibody-based (serum) therapies were first used to treat human infections in the 1890s. In the early 20th century, serum therapy was used to treat a variety of bacterial infections, including Coryneobacterium diphtheriae, Streptococcus pneumoniae, Neisseria menigitidis, and others. However, when antimicrobial pharmaceuticals were discovered in the mid 1930s, serum therapy of bacterial infections was quickly abandoned. In addition, serum therapy included the development of side effects, such as fevers, chills, and allergic reactions. A delayed toxic reaction of serum therapy was serum sickness. The use of chicken egg yolk antibodies (IgYs) has attracted researchers' interest because of the absence of considerable side effects. IgY can thus be an alternative method for providing infection control. Comparing our results with those obtained by Zhen shows that the IgY produced here was effective at lower concentrations (Zhen et al. 2008).

In conclusion, the encouraging results of this study indicate that anti-S. aureus IgY obtained from hens immunized with $S$. aureus ATCC 33593 may provide an interesting alternative to antibiotic use in the management of $S$. aureus infectious in humans and animals. However, many problems remain to be resolved for the clinical application, such as the effect of IgY in these organisms, the persistence of the effect of IgY after cessation of the application, and the potential in eradicating an established infection. Therefore, more studies must be conducted.

Acknowledgment: We thank Prof. Kildare Miranda and Prof. Aldo Shimoya for critical reading of the manuscript. The study was supported by grants from Universidade Estadual do Norte Fluminense Darcy Ribeiro (UENF).

\section{REFERENCES}

Akita EM, Nakai S (1992) Immunoglobulin from egg yolk: Isolation and purification. J Food Sci 57:626-634

Allison JR (1985) Antibiotic residues in milk. Br Vet J 141:9-16

Balaban N, Rasooly A (2000) Staphylococcal enterotoxins. Int J Food Microbiol 61:1-10

Belschner AP, Hallberg JW, Nickerson SC et al (1996) Staphylococcus aureus mastitis therapy revisited. In Proc 35th Annu Mtg Natl Mastitis Council, p 116-122

Berghman LR, Abi-Ghanem D, Waghela SD et al (2005) Antibodies: an alternative for antibiotics? Poult Sci 84:660-666

Bohach GA, Foster TJ (2000) Staphylococcus aureus exotoxins. In: Fischetti VA, Novick RP, Ferretti JJ et al (eds) Gram-positive pathogens. ASM Press, Washington DC, pp 367-378

Booth JM, Harding F (1986) Testing for antibiotic residues in milk. Vet Rec 119:565-569

Buchwald UK, Pirofski L (2003) Immune therapy for Infectious diseases at the dawn of the 21st century: the past, present and future role of antibody therapy, therapeutic vaccination and biological response modifiers. Curr Pharm Des 9:945-968

Casadevall A (1996) Antibody-based therapies for emerging infectious diseases. Emerg Infect Dis 2:200-208

Casadevall A, Scharff MD (1994) Serum therapy revisited: Animal models of infection and development of passive antibody therapy. Antimicrob Agents Chemother 38:1695-1702

Chambers HF (2001) The changing epidemiology of Staphylococcus aureus? Emerg Infect Dis 7:178-182

Crossley KB, Archer GL (1997) The Staphylococci in Human Disease. Churchill Livingstone, New York, pp 565-582

Doyle ME (2001) Alternatives to Antibiotic Use for Growth Promotion in Animal Husbandry. FRI Briefings

Fioretto F, Cruz C, Largeteau A, Sarli TA et al (2005) Inactivation of Staphylococcus aureus and Salmonella enteritidis in tryptic soy broth and caviar samples by high pressure processing. Braz J Med Biol Res 38:1259-1265

Fox LK, Bayles KW, Bohach GA (2000) Staphylococcal bovine mastitis. In: Honeyman A, Friedman H, Bendinelli M (eds) Staphylococcal infection and immunity. Kluwer Academic/ /Plenum Publishers, New York, pp 271-294

Hatta H, Kim M, Yamamoto T (1994) A novel isolation method for hen egg yolk antibody, "IgY". Agric Biol Chem 54:2531-2535

Jablonski LM, Bohach GA (2001) Staphylococcus aureus. In: Doyle MP, Beuchat LR, Montville TJ (eds) Food Microbiology: Fundamentals and Frontiers, 2nd edn. ASM Press, Washington DC, pp 410-434

Kirk JH, Berry IA, Gardner JM (2002) Dry cow antibiotic treatment in a herd with low contagious mastitis prevalence. In Proc 36th Annu Mtg Natl Mastitis Council, p 164

Lindberg E, Adlerberth I, Wold AE (2004) Antibiotic resistance in Staphylococcus aureus colonizing the intestines of Swedish infants. Clin Microbiol Infect 10:890-894 
Livemore D (2000): Antibiotic resistance in staphylococci. Int J Antimicrob Agents 16(suppl 1):S3-10

Marshall MJ, Bohach GA, Boehm DF (2000) Characterization of Staphylococcus aureus beta-toxin induced leukotoxicity. J Nat Toxins 9:125-138

McEwen SA, Black WD, Meek AH (1992) Antibiotic residues (bacterial inhibitory substances) in the milk of cows under label and extra-label conditions. Can Vet J 33:527-534

Mine Y, Kovacs-Nolan J (2002) Chicken egg yolk antibodies as therapeutics in enteric infectious disease: a review. J Med Food 5:159-169

Moreillon P, Que YA, Glauser MP (2005) Staphylococcus aureus. In: Mandell GL, Bennett JE, Dolin R (eds) Principles and practice of infectious diseases, 6th edn. Elsevier Churchill Livingstone, Philadelphia, pp 2321-2351

Nickerson SC, Owens WE, Boddie RL (1995) Mastitis in dairy heifers: initial studies on prevalence and control. J Dairy Sci 78:1607-1618

Oliver SP, Lewis MJ, Gillespie BE et al (1992) Influence of prepartum antibiotic therapy on intramammary infections in primigravid heifers during early lactation. J Dairy Sci 75:406-414

Pereira MS, Leal NC, Leal TC et al (2002) Typing of human and bovine Staphylococcus aureus by RAPD-PCR and ribotyping-PCR. Lett Appl Microbiol 35:32-36

Petrie A, Watson P (1999) Non-parametric statistical tests. In: Watson P (ed) Statistics for Veterinary and Animal Science. Blackwell Science, pp 138-152
Roberson JR, Fox LK, Hancock DD et al (1994) Ecology of Staphylococcus aureus isolated from various sites on dairy farms. J Dairy Sci 77:3354-3364

Roghmann M, Taylor KL, Gupte A et al (2005) Epidemiology of capsular and surface polysaccharide in Staphylococcus aureus infections complicated by bacteraemia. J Hosp Infect 59:27-32

Schade R, Calzado EG, Sarmiento R et al (2005) Chicken egg yolk antibodies (IgY-technology): a review of progress in production and use in research and human and veterinary medicine. Altern Lab Anim 33:129-154

Schade R, Henklein P, Hlinak A (1997) Egg yolk antibody: state of the art and advantageous use in the life sciences. In: Animal Alternatives, Welfare and Ethics. Elsevier, Amsterdam, pp 973-981

Shin JH, Yang M, Nam SW et al (2002) Use of egg yolk-derived immunoglobulin as an alternative to antibiotic treatment for control of Helicobacter pylori infection. Clin Diagn Lab Immunol 9:1061-1066

Sol J, Sampimon OC, Snoep JJ et al (1997) Factors associated with bacteriological cure during lactation after therapy for subclinical mastitis caused by Staphylococcus aureus. J Dairy Sci 80:2803-2808

Sunwoo HH, Lee EN, Menninen K et al (2002) Growth inhibitory effect of chicken egg yolk antibody (IgY) on Escherichia coli O157:H7. J Food Sci 67:1486-1494

Zhen YH, Jin LJ, Guo J et al (2008) Characterization of specific egg yolk immunoglobulin ( $\operatorname{Ig} \mathrm{Y})$ against mastitis-causing Staphylococcus aureus. J Appl Microbiol 105:1529-1535 